\title{
Obituary for Franz Kangler CM (May 27, 1950-February 23, 2021)
}

Franz Kangler, an Austrian priest of the Congregation for the Mission of St. Vincent de Paul (Lazarists), had joined the community in 1968. In 1977, he started teaching English at St. George's College in Istanbul. In 1983, he became the superior of the Lazarist community and was appointed director of the Austrian St. George's College. From 1994-2003, he served as Inspector of the Austrian Lazarist Province. In 2010, he retired as College director, remaining the representative of the Lazarist tutelage of the Institute. In appreciation of his work, he received the honorary decoration for services to the Republic of Austria. In 2015, he was elected first Provincial of the newly established Austro-German Province. In 2018, he resigned due to illness.

Franz Kangler has always shown a deep attachment to his second homeland, Turkey, where he worked from the beginning of his life as a Lazarist. Getting to know Turkey and trying to understand its cultural peculiarities was an essential element of his daily work. For Kangler, fulfilling the educational mission - part of the Lazarist charisma - meant tirelessly building cultural bridges and crossing borders, a source a great enrichment to him.

He exemplified the same passion for diversity within interreligious and ecumenical relations. At St. George's, he valued helping students learn about the religious traditions of their families, and helped them perceive the richness of religious diversity in a "city-continent" like Istanbul. As for ecumenism, he was a tireless animator of inter-community relations between the German-speaking, Catholic, and Lutheran congregations in Istanbul.

Franz Kangler died in the midst of the Covid-19 Pandemic, a particularly critical time for Turkey.

\section{Claudio Monge OP}

Dominican Study, Istanbul

Consultant to the Pontifical Council for Interreligios Dialogue 